\title{
Peningkatan Kemampuan Membaca Permulaan Melalui Metode Struktural Analitik Sintetik
}

\author{
Yanie Muriani ${ }^{1}$, Zulela MS $^{2}$, Muchlas Suseno $^{3}$ \\ Universitas Negeri Jakarta \\ 1yaniemuriani@gmail.com, 22 zulelams@yahoo.co.id, \\ susenosaja@yahoo.com
}

\begin{abstract}
The purpose of this study was to describe the beginning reading skill through Structural Analitic Sintetic Methods in the class I of Elemantary School Ciampea 02 Bogor. The method used is descriptive research type of class action. The subjek of the reseach were teacher and students of 20 people. The technique used is observation. Data collection tool was a teacher and student observation sheets. This research was conducted through a twice cycle, the research procedure using the planning, implementation, observation, and reflection. The results obtained are fluentthe beginning reading skills of students in the first cycle reaches $65 \%$, reaching $85 \%$. The second cycle, it was increased 20\%. By using Structural Analitic Sintetic Methods can improve the beginning reading skills of student fluent in Indonesian language learning on the class I of Elementary School Ciampea 02 Bogor.
\end{abstract}

Keywords: The Beginning Reading Skill, Structural Analitic Sintetic Methods $(S A S)$

Abstrak: Penelitian ini bertujuan untuk mendeskripsikan peningkatan
kemampuan membaca permulaan melalui metode Struktural Analitik
Sintetik (SAS) di kelas I Sekolah Dasar Negeri Ciampea 02 Kabupaten
Bogor. Metode penelitian yang digunakan adalah deskriptif, jenis
penelitian tindakan kelas. Subyek penelitian adalah guru dan siswa
berjumlah 20 orang. Teknik yang digunakan adalah observasi. Alat
pengumpulan data adalah lembar observasi guru dan siswa. Penelitian
ini dilaksanakan melalui II siklus, prosedur penelitian menggunakan
tahap perencanaan, pelaksanaan, observasi, dan refleksi. Hasil
penelitian yang diperoleh adalah keterampilan membaca permulaan
siswa pada siklus I mencapai $65 \%$, dan siklus II mencapai $85 \%$,
meningkat 20\%. Dengan menggunakan metode Struktural Analitik
Sintetik (SAS) dapat meningkatkan kemampuan membaca

AR-RIAYAH : Jurnal Pendidikan Dasar vol. 2, no. 1, 2018

STAIN Curup - Bengkulu| p ISSN 2580-362X; e ISSN 2580-3611

http://journal.staincurup.ac.id/index.php/JPD 
permulaan siswa di kelas I Sekolah Dasar Negeri Ciampea 02 Kabupaten Bogor.

Kata Kunci : Membaca Permulaan, Metode Struktural Analitik. Sintetik (SAS)

\section{PENDAHULUAN}

Perwujudan pendidikan bermutu memiliki relevansi dengan kebutuhan dan karakteristik peserta didik yang mampu bersaing dalam perkembangan ilmu pengetahuan dan teknologi di era globalisasi, serta mampu menciptakan masyarakat yang memiliki kemampuan membaca. Membaca merupakan bagian terpenting dalam perkembangan akademik seorang anak pada usia sekolah. Menurut Far dalam H. Dalman mengungkapkan "reading is the hear of education" artinya membaca merupakan jantung pendidikan.1

Fase perkembangan kanak-kanak tengah dan akhir anak sekolah dasar berlangsung pada usia (6 sampai 11 tahun), mereka mulai harus menguasai keterampilan-keterampilan dasar membaca, menulis dan berhitung, memasuki dunia yang lebih luas dengan budayanya dan mulai memperhatikan pencapaian prestasi serta pengendalian diri khususnya dalam hal membaca. ${ }^{2}$

Berdasarkan hasil pengamatan di lapangan yang menunjukkan bahwa kemampuan membaca permulaan peserta didik kelas I Sekolah Dasar Negeri Ciampea 02 masih rendah, hal ini terbukti dari 35 peserta didik, hanya 15 anak yang mampu membaca dengan baik, sedangkan sisanya sebanyak 20 anak masih belum mampu membaca dengan baik.

Sehubungan dengan permasalahan yang telah ditemukan berdasarkan data hasil pengamatan pada proses pembelajaran tematik di kelas I, untuk meningkatkan kemampuan peserta didik dalam membaca permulaan maka perlu diciptakan suasana pembelajaran yang menyenangkan, melibatkan peserta didik secara aktif, berpusat pada peserta didik dan menetapkan strategi pembelajaran dengan metode membaca permulaan sesuai dengan karakteristik peserta didik.

Kartono berpendapat bahwa metode pembelajaran yang digunakan dalam mata pelajaran Bahasa Indonesia pada proses pembelajaran membaca

1 Dalman, Keterampilan Membaca (Jakarta: Raja Grafindo Persada, 2013), 115.

2 Mulyani Sumantri dan Nana Syaodih, Perkembangan Peserta Didik (Jakarta: Universitas Terbuka, 2007), 1.9. 
permulaan, yakni: metode Eja, metode Suku Kata, metode Kata Lembaga, metode Global, dan metode SAS (Struktural Analisis Sintesis). Metode Global dan metode SAS (Struktural Analisis Sintesis) memiliki kesamaan dalam hal pengambilan titik tolak pembelajaran membaca menulis permulaan, proses pembelajaran diawali dengan memperkenalkan struktur kalimat sebagai dasar bagi pembelajaran membaca menulis permulaan. Adapun perbedaannya pada proses pembelajaran membaca menulis permulaan pada metode global tidak disertai dengan proses sintesis, sedangkan metode SAS (Struktural Analisis Sintesis) menuntut adanya proses analisis dan sintesis. Pengembangan metode SAS (Struktural Analisis Sintesis) dilandasi oleh filsafat strukturalisme, psikologi Gestalt, landasan pedagogik dan landasan kebahasaan. ${ }^{3}$

Menurut Solchan, metode Struktural Analitik Sintetik merupakan metode yang mengawali pembelajarannya dengan menampilkan dan memperkenalkan sebuah kalimat utuh. Kalimat utuh yang dijadikan tonggak dasar diuraikan ke dalam satuan-satuan bahasa yang lebih kecil yang disebut kata. Proses analisis atau penguraian ini terus berlanjut hingga sampai pada wujud satuan bahasa terkecil yang tidak bisa diuraikan lagi, yakni huruf-huruf. ${ }^{4}$

Penelitian lain yang relevan pernah dilakukan sebelumnya oleh peneliti Ernalis yang hasil penelitian menunjukkan bahwa : (1) guru telah menguasai keterampilan merancang pembelajaran membaca dan menulis permulaan di sekolah dasar dengan menggunakan metode SAS ; 2) komponen-komponen pembelajaran seperti aspek: materi, strategi, metode, media, sumber belajar serta evaluasi yang dikembangkan guru telah merujuk pada tuntutan metode SAS; 3) metode SAS dalam pembelajaran membaca dan menulis permulaan, dapat diimplementasikan guru dengan siswa kelas satu sekolah dasar yang ditunjukkan peran aktif siswa kelas satu sekolah dasar; 4) penerapan metode SAS mampu meningkatkan aktivitas guru dan kreativitas siswa dalam proses pembelajaran. $^{5}$

3 Kartono, dkk., Guru Kelas SD (Jakarta: Badan Pengembangan Sumber Daya Manusia Pendidikan Kebudayaan dan Penjaminan Mutu Pendidikan/BPSDMP-PMP), 21. h. 6.22 .

4 Solchan T.W., Pendidikan Bahasa Indonesia di SD (Jakarta: Universitas Terbuka, 2009),

5 Ernalis, "Penggunaan Metode SAS dalam Pembelajaran Membaca Menulis Permulaan di Sekolah Dasar," (Tesis, Universitas Pendidikan Indonesia, 2006), http://file.upi.edu/Direktori/JURNAL/JURNAL_MIMBAR_PENDIDIKAN/MIMBAR_N O_4_2006/Penggunaan_Metode_SAS_dalam_Pembelajaran_Membaca_dan_Menulis_Permula an_di_Sekolah_Dasar. pdf ._(diakses 21 Maret 2018). 
Berdasarkan temuan permasalahan di kelas I SDN Ciampea 02 dan hasil penelitian sebelumnya, maka penulis selaku peneliti merasa tertarik untuk mencari informasi tentang penggunaan metode Struktural Analitik Sintetik untuk meningkatkan kemampuan membaca permulaan pada peserta didik kelas I yang pada akhirnya penulis merasa perlu melakukan penelitian tindakan dalam proses pembelajaran membaca permulaan di kelas I SD Negeri Ciampea 02 Kabupaten Bogor.

\section{LANDASAN TEORI}

Kurt Lewin orang yang pertama kali memperkenalkan action research atau penelitian tindakan. Konsep pokok penelitian tindakan model Kurt Lewin terdiri dari empat komponen yaitu perencanaan, tindakan, pengamatan, dan refleksi. ${ }^{6}$ Classroom action research menurut Lewin (dalam Grundy \& Kemmis) adalah:

"a term used to describe a family of activities in curiculum development, professional development, school improvement programs, and system planning and policy development. These activities have in common the indification, and then systematically submitied to observation, reflection and change participants in the action being considered are integraly involved in all of the activities.

Stephen Kemmis dan McTaggart mengembangkan model penelitian tindakan Kurt Lewin, selanjutnya mengemukakan bahwa penelitian tindakan adalah sebuah bentuk inkuri reflektif yang dilakukan secara kemitraan mengenai situasi sosial tertentu (termasuk pendidikan) untuk meningkatkan rasionalitas dalam keadilan dari : 1) kegiatan praktek sosial atau pendidikan mereka, 2) pemahaman mereka mengenai kegiatan-kegiatan praktek pendidikan ini, 3) situasi yang memungkinkan terlaksananya kegiatan praktek ini. ${ }^{8}$

Model penelitian Kemmis dan McTagart merupakan model penelitian yang dikembangkan dari model penelitian Kurt Lewin, hanya saja komponen acting dan observing dijadikan satu kesatuan karena keduanya merupakan tindakan yang tidak terpisahkan, terjadi dalam waktu yang sama. ${ }^{9}$

6 Ibid., 20.

7 Shirly Grundy, Sthepen Kemmis, Educational Research in Australia the state of the art (an overview), The Action Research Reader, (Australia: Deakin Univesity: 1198), 21.

8 Rochiati Wiriatmadja, Metode Penelitian Tindakan Kelas (Bandung: Remaja Rosdakarya, 2008), 12.

9 Trianto, Panduan Penelitian Tindakan Kelas (classroom Action Research) Teori \& praktek, (Jakarta: Prestasi Pustaka Raya, 2011), 30. 
Secara skematis dalam perencanaannya, Kemmis menggunakan sistem spiral refleksi diri yang dimulai dengan rencana (planning), tindakan (acting), pengamatan (observing), refleksi (reflecting), dan perencanaan kembali. Penelitian yang dikembangkan oleh Kemmis dan McTaggart menjelaskan secara detail program-program berkelanjutan bagi para guru yang bermaksud untuk terlibat dalam penelitian tindakan. ${ }^{10}$ Adapun gambaran siklus dalam model ini sebagai berikut :

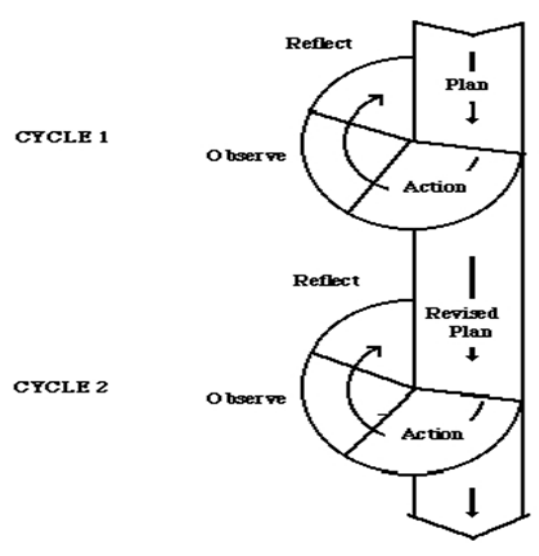

Kemampuan tidak datang dengan sendirinya. Kemampuan hanya dapat diperoleh dengan berusaha, dipraktekkan, dan banyak latihan. Kemampuan merupakan daya untuk melakukan suatu tindakan sebagai hasil bawaan dan latihan. Kemampuan menunjukkan bahwa suatu tindakan itu dilakukan pada saat sekarang. Kemampuan yang dimiliki oleh seseorang itu bisa merupakan bawaan sejak lahir dan juga bisa didapat dari hasil latihan-latihan yang ia lakukan dengan ketekunan. ${ }^{11}$

Sementara menurut Jhonson yang dikutip dalam Wijaya dkk. Kemampuan adalah sebagai perilaku rasional untuk mencapai tujuan yang dipersyaratkan sesuai kondisi yang diharapkan. ${ }^{12}$ Jadi, hal ini dapat diartikan sebagai suatu keadaan di mana untuk mencapai suatu tujuan diperlukan suatu usaha dan bagaimana situasi dan kondisi itu dapat diupayakan dan bagaimana situasi dan kondisi agar sesuai dengan keinginannya.

10 David Hopkins, Panduan Guru Penelitian Tindakan Kelas (A Teacher's Guide Classroom Research) (Yogyakarta: Pustaka Belajar, 2011), 91.

11 S.C. Utami Munandar, Mengembangkan Bakat dan Kreatifitas Anak Sekolab (Jakarta:PT Gramedia, 1992), 17

12 Cece Wijaya, Kemampuan Dasar Guru dalam Proses Belajar Mengajar, (Bandung: Remaja Rosdakarya, 1992), 8 
Berbeda dengan kemampuan dalam proses pembelajaran berhubungan erat dengan bagaimana cara guru mengimplementasikan perencanaan pembelajaran, yang mencakup kemampuan menerapkan keterampilan dasar mengajar dan keterampilan mengembangkan berbagai model pembelajaran yang dianggap mutakhir. ${ }^{13}$

Membaca adalah suatu proses yang dilakukan serta digunakan oleh pembaca untuk memperoleh kesan, yang hendak disampaikan oleh penulis melalui media kata-kata atau bahasa tulis. Suatu proses yang menuntut agar kelompok kata yang merupakan suatu kesatuan akan terlihat dalam suatu pandangan sekilas dan makna kata-kata secara individual akan dapat diketahui. Kalau hal ini tidak terpenuhi, pesan yang tersurat dan yang tersirat tidak akan tertangkap atau dipahami, dan proses membaca itu tidak terlaksana dengan baik. $^{14}$

Sementara itu , Bob Harjanto berpendapat bahwa membaca merupakan serangkaian informasi yang berperan sebagai nutrisi bagi mental anak. ${ }^{15}$ Menurut Sabarti Akhadiah, Maidar G Arsjad, Sakura H.Ridwan, Zulfahnur dan Mukti membaca merupakan suatu kesatuan kegiatan yang terpadu yang mencakup beberapa kegiatan seperti mengenali huruf dan kata-kata, menghubungkannya dengan bunyi serta maknanya, serta menarik kesimpulan mengenai maksud bacaan. ${ }^{16}$

Menurut pendapat A.S Broto, yang dimaksud dengan pengajaran membaca permulaan yang dapat dinilai dengan membaca gambar, kemudian membaca gambar yang disertai tulisan dan dilanjutkan dengan membaca tulisan. ${ }^{17}$ Glass dalam Mulyono berpendapat, ada empat langkah dalam mengajar membaca permulaan yaitu : 1). Mengidentifkasi keseluruhan kata, huruf dan bunyi kelompok-kelompok huruf, 2). Mengucapkan bunyi-bunyi kelompok huruf dan huruf, 3). Menyajikan kepada anak huruf atau kelompok huruf dan meminta untuk mengucapkannya, 4). Guru mengambil beberapa

13 Wina Sanjaya, Strategi Pembelajaran Berorientasi Standar Proses Pendidikan (Jakarta: Kencana, 2007), 141.

14 Tarigan, Henri Guntur, Membaca Sebagai Suatu Keterampilan Berbahasa, (Bandung : Angkasa, 2008), 7

15 Bob Harjanto, Merangsang dan Melejitkan Minat Baca Anak Anda, (Yogyakarta: Manika, 2011), 11

16 Sabarti Akhadiah, Maidar G Arsjad, Sakura H.Ridwan, Zulfahnur dan Mukti, Bahasa Indonesia I (Depdikbud : 1993), 22

17 A.S Broto, Metodologi Proses Belajar Mengajar Berbahasa (Solo : Tiga Serangkai 1982), 59 
huruf pada susunan kata tertulis dan anak diminta mengucapkan kelompok huruf yang masih tersusun. ${ }^{18}$

Pengajaran membaca permulaan lebih ditekankan pada pengembangan kemampuan dasar membaca. Pembelajaran bahasa Indonesia diarahkan untuk meningkatkan kemampuan peserta didik untuk berkomunikasi dalam bahasa Indonesia dengan baik dan benar, baik secara lisan maupun secara tertulis, serta menumbuhkan apresiasi terhadap hasil karya kesastraan manusia Indonesia. ${ }^{19}$

Guru memegang peran penting dalam proses pembelajaran. Wina Sanjaya berpendapat bahwa metode adalah cara yang digunakan untuk mengimplementasikan rencana yang sudah disusun dalam kegiatan nyata agar tujuan yang telah disusun tercapai secara optimal. ${ }^{20}$

\section{METODE PENELITIAN}

Jenis Penelitian ini adalah penelitian tindakan kelas dengan menggunakan pendekatan kuantitatif dan kualitatif. Waktu dan Tempat Penelitian Tempat yang digunakan untuk penelitian yaitu SD Negeri Ciampea 02 Kabupaten Bogor dan waktu pelaksanaan penelitian dilaksanakan selama kurang lebih 4 bulan, yakni dari bulan Januari sampai dengan April 2018. Subjek Penelitian Subjek penelitian merupakan jumlah siswa 35 anak, terdiri dari 18 siswa laki-laki dan 17 siswa perempuan.

Prosedur Desain yang digunakan dalam penelitian ini adalah model Kemmis dan Mc Taggart yakni:

a. Tahap perencanaan dilakukan dengan mengadakan pertemuan antara peneliti, guru kelas, dan guru pendamping khusus untuk mendiskusikan soal pretes, materi, skenario pembelajaran, dan penyusunan Rencana Pembelajaran Individual (RPI).

b. Tahap pelaksanaan atau tindakan dilakukan 3 kali pada tiap siklus, setiap pertemuan adalah 35 menit. Dan melakukan tes setiap akhir siklus, pada pertemuan ke-3 untuk mengukur kemampuan pada anak. Pada tahap ini guru bertindak sebagai kolaborator pengajar dan peneliti sebagai pengamat.

18 Mulyono, Abdurrachman, Pendidikan Bagi Anak Berkesulitan Belajar (Jakarta : Rineka Cipta, 1999), 200

19 Kurikulum Tingkat Satuan Pendidikan SDN Ciampea 02

20 Wina Sanjaya, Strategi Pembelajaran Berorientasi Standar Proses Pendidikan (Jakarta: Prenada Media Group, 2010), 147 
c. Tahap Pengamatan dilakukan untuk mengamati kemampuan membaca anak berkesulitan membaca. Pengamatan dilakukan dengan menggunakan instrumen observasi

d. Tahap Refleksi merupakan kegiatan diskusi antara guru kolaborator dan peneliti untuk menganalisis hasil pelaksanaan pembelajaran membaca dengan menggunakan metode SAS (Struktur Analitik Sintetik).21

Penelitian ini menggunakan beberapa teknik pengumpulan data diantaranya yaitu tes, observasi, wawancara, dan dokumentasi. Tes berfungsi untuk mengukur kemampuan siswa dalam penguasaan materi pembelajaran menurut Wina Sanjaya. ${ }^{22}$ Dalam penelitian ini tes dilakukan untuk mengetahui tingkat kemampuan membaca permulaan sebelum tindakan dan sesudah tindakan. Observasi penelitian ini menggunakan observasi partisipatif.

Observasi ini dilakukan dengan menggunakan chek list yang telah dibuat oleh peneliti pada lembar observasi. Selain itu peneliti membuat catatan harian untuk pendukung kelengkapan data. Wawancara yang digunakan adalah wawancara tidak terstruktur. Dokumentasi merupakan metode pengumpulan data yang bertujuan untuk memperoleh informasi terkait indentitas, catatan siswa, hasil tes (pretest dan postest), dokumen pelaksanaan kegiatan tindakan, dan catatan kegiatan tindakan. Teknik analisis data yang digunakan dalam penelitian ini menggunakan deskriptif dengan presentase. Sugiyono menyatakan bahwa gabungan data kualitatif yang diperoleh untuk memperkuat data yang diperoleh secara kuantitatif. Kualitatif dalam analisis berupa deskripsi analisis data. Data yang dideskripsikan berupa data tes, observasi, dan wawancara. ${ }^{23}$

\section{HASIL PENELITIAN}

Berdasarkan data observasi siklus I, yang diperoleh mengenai hasil pengamatan kemampuan guru dalam merancang pembelajaran menunjukkan bahwa secara keseluruhan kegiatan pembelajaran meningkatkan kemampuan membaca lancar dengan menggunakan metode Struktural Analitik Sintetik (SAS), mampu dilaksanakan oleh guru dengan kriteria baik. Hal ini ditunjukkan dengan perolehan skor rata-rata 3,2. Data kemampuan guru dalam merancang pembelajaran sikluas I sebagai berikut :

21 Wijaya Kusumah dan Dedi Dwitagama, Mengenal Penelitian Tindakan Kelas (Jakarta: PT. Indeks, 2009), 20.

22 Ibid., 156

23 Ibid., 77. 
Tabel 1. :Kemampuan Guru Merancang Pembelajaran Siklus I

\begin{tabular}{|c|l|c|}
\hline No & \multicolumn{1}{|c|}{ Aspek yang diamati } & Skor \\
\hline 1 & $\begin{array}{l}\text { Kelengkapan cakupan rumusan kelengkapan tujuan } \\
\text { pembelajaran }\end{array}$ & 3 \\
\hline 2 & Kesesuian tujuan pembelajaran dengan Kompetensi Dasar & 4 \\
\hline 3 & Kesesuaian materi dengan tujuan pembelajaran & 4 \\
\hline 4 & Keruntutan uraian materi & 4 \\
\hline 5 & Kesusuain media dengan tujuan pembelajaran & 3 \\
\hline 6 & Kesesuaian media dengan materi pembelajaran & 2 \\
\hline 7 & Kesesuaian metode dengan tujuan pembelajaran & 3 \\
\hline 8 & Kesesuaian metode dengan materi pembelajaran & 3 \\
\hline 9 & Kesesuaian teknik penilaian dengan tujuan pembelajaran & 3 \\
\hline 10 & Kelengkapan intrumen penilaian & $\mathbf{3 2}$ \\
\hline & Skor total & $\mathbf{3 , 2}$ \\
\hline & Skor rata-rata & \\
\hline
\end{tabular}

Berdasarkan data hasil observasi siklus I, kemampuan guru dalam melaksanakan pembelajaran menunjukkan bahwa secara keseluruhan kegiatan pembelajaran meningkatkan kemampuan membaca permulaan siswa kelas I dengan menggunakan metode Struktural Analitik Sintetik (SAS) dilaksanakan oleh guru dengan kriteria cukup. Gambaran datanya sebagai berikut :

Tabel 2. : Kemampuan Guru Melaksanakan Pembelajaran Siklus I

\begin{tabular}{|c|l|c|}
\hline No & \multicolumn{1}{|c|}{ Aspek Yang Diamati } & Skor \\
\hline 1 & Mekondisikan siswa & 3 \\
\hline 2 & Melakukan kegiatan apersepsi & 2 \\
\hline 3 & Menyampaikan tujuan pembelajaran & 3 \\
\hline 4 & Menunjukan penguasaan materi & 3 \\
\hline 5 & Menyampaikan materi dari yang mudah ke yang sukar & 4 \\
\hline
\end{tabular}


10 | AR-RIAYAH : Jurnal Pendidikan Dasar vol. 2, no. 1, 2018

\begin{tabular}{|c|c|c|}
\hline 6 & Mengaitkan materi dengan realitas kehidupan & 2 \\
\hline 7 & $\begin{array}{l}\text { Melaksanakan pembelajaran sesuaidengan kompetensi yang } \\
\text { akan dicapai }\end{array}$ & 3 \\
\hline 8 & Melaksanakan pembelajaran secara runtut & 3 \\
\hline 9 & Apersepsi & 3 \\
\hline 10 & Memperlihatkan gambar & 3 \\
\hline 11 & Membaca gambar & 3 \\
\hline 12 & Membaca kalimat & 3 \\
\hline 13 & Membaca suku kata & 3 \\
\hline 14 & Membaca huruf & 3 \\
\hline 15 & Bertanya hal yang belum jelas & 2 \\
\hline 16 & Melaksanakan pembelajaran sesuai dengan alokasi waktu & 2 \\
\hline 17 & $\begin{array}{l}\text { Menggunakan media secara efektif (mangkus) dan efesien } \\
\text { (sangkil) }\end{array}$ & 4 \\
\hline 18 & Melibatkan siswa dalam pemanfaatkan media & 3 \\
\hline 19 & Menumbuhkan partisipasi dalam pembelajaran & 3 \\
\hline 20 & Melakukan penilaian akhir sesuai dengan kompetensi dasar & 3 \\
\hline 21 & Menggunakan bahasa lisan secara efektif dan lancar & 3 \\
\hline 22 & Menggunakan bahasa tulis secara baik dan benar & 3 \\
\hline 23 & Melakukan refleksi & 2 \\
\hline 24 & $\begin{array}{l}\text { Melibatkan siswa dalam merangkum dalam kegiatan } \\
\text { pembelajaran }\end{array}$ & 2 \\
\hline & Skor total & 68 \\
\hline \multicolumn{2}{|r|}{ Skor rata-rata } & 2,83 \\
\hline
\end{tabular}

Hal ini ditunjukkan dengan perolehan skor rata-rata 2,83. Kemudian berdasarkan data yang diperoleh berkaitan dengan keterampilan membaca permulaan siswa kelas I yang dijabarkan dalam bentuk : kelancaran, lafal, 
intonasi dapat dilihat dengan perolehan skor rata-rata 65\%. Adapun data lengkapnya sebagai berikut :

Tabel 3 : Hasil Kemampuan Membaca Permulaan Siswa Siklus I

\begin{tabular}{|l|c|c|}
\hline \multicolumn{1}{|c|}{ Kategori } & Jumlah & Persentase \\
\hline Sangat lancar & 4 orang & $20 \%$ \\
\hline Lancar & 9 orang & $45 \%$ \\
\hline Kurang lancar & 5 orang & $25 \%$ \\
\hline Tidak lancar & 2 orang & $10 \%$ \\
\hline
\end{tabular}

Berdasarkan hasil observasi dalam pelaksanaan siklus I, memberikan gambaran bahwa metode Struktural Analitik Sintetik (SAS) yang peneliti gunakan cukup berhasil meningkatkan keterampilan membaca permulaan, walaupun belum sesuai dengan target yang diharapkan.

Berkenaan dengan observasi pada siklus II, diperoleh mengenai hasil pengamatan kemampuan guru dalam merancang pembelajaran, menunjukkan bahwa secara keseluruhan kegiatan pembelajaran meningkatkan kemampuan membaca permulaan dengan menggunakan metode Sintetik Analitik Sintetik (SAS) mampu dilaksanakan oleh guru dengan kriteria baik. Hal ini ditunjukkan dengan perolehan skor rata-rata sebesar 3,4 sebagai berikut :

Tabel 4 : Kemampuan Guru Merancang Pembelajaran

Siklus II

\begin{tabular}{|c|l|c|}
\hline No & Aspek yang diamati & Skor \\
\hline 1 & $\begin{array}{l}\text { Kelengkapan cakupan rumusan kelengkapan tujuan } \\
\text { pembelajaran }\end{array}$ & 3 \\
\hline 2 & Kesesuian tujuan pembelajaran dengan Kompetensi Dasar & 4 \\
\hline 3 & Kesesuaian materi dengan tujuan pembelajaran & 4 \\
\hline 4 & Keruntutan uraian materi & 3 \\
\hline 5 & Kesusuain media dengan tujuan pembelajaran & 3 \\
\hline 6 & Kesesuaian media dengan materi pembelajaran & 3 \\
\hline
\end{tabular}


12 | AR-RIAYAH : Jurnal Pendidikan Dasar vol. 2, no. 1, 2018

\begin{tabular}{|c|l|c|}
\hline 7 & Kesesuaian metode dengan tujuan pembelajaran & 4 \\
\hline 8 & Kesesuaian metode dengan materi pembelajaran & 3 \\
\hline 9 & Kesesuaian teknik penilaian dengan tujuan pembelajaran & 3 \\
\hline 10 & Kelengkapan intrumen penilaian & 3 \\
\hline \multirow{2}{*}{ Skor total } & $\mathbf{3 4}$ \\
\hline & Skor rata-rata & $\mathbf{3 , 4}$ \\
\hline
\end{tabular}

Berdasarkan data observasi yang diperoleh mengenai hasil pengamatan kemampuan guru dalam melaksanakan pembelajaran menunjukkan bahwa secara keseluruhan kegiatan pembelajaran meningkatkan kemampuan membaca permulaan dengan menggunakan metode Sintetik Analitik Sintetik (SAS) dilaksanakan oleh guru dengan kriteria baik. Hal ini ditunjukkan dengan perolehan skor rata-rata sebesar 3,25 sebagai berikut :

Tabel 5 : Kemampuan Guru Melaksanakan Pembelajaran Siklus II

\begin{tabular}{|c|l|c|}
\hline No & Aspek Yang Diamati & Skor \\
\hline 1 & Mekondisikan siswa & 3 \\
\hline 2 & Melakukan kegiatan apersepsi & 3 \\
\hline 3 & Menyampaikan tujuan pembelajaran & 3 \\
\hline 4 & Menunjukan penguasaan materi & 3 \\
\hline 5 & Menyampaikan materi dari yang mudah ke yang sukar & 4 \\
\hline 6 & Mengaitkan materi dengan realitas kehidupan & 3 \\
\hline 7 & $\begin{array}{l}\text { Melaksanakan pembelajaran sesuaidengan kompetensi } \\
\text { yang akan dicapai }\end{array}$ & 3 \\
\hline 8 & Melaksanakan pembelajaran secara runtut & 3 \\
\hline 9 & Apersepsi & 4 \\
\hline 10 & Guru memperlihatkan gambar & 4 \\
\hline 11 & Membaca gambar & 3 \\
\hline 12 & Membaca kalimat & 4 \\
\hline 13 & Membaca suku kata & 3 \\
\hline
\end{tabular}




\begin{tabular}{|c|l|c|}
\hline 14 & Membaca huruf & 4 \\
\hline 15 & Bertanya jawab hal yang belum jelas & 3 \\
\hline 16 & Melaksanakan pembelajaran sesuai dengan alokasi waktu & 4 \\
\hline 17 & $\begin{array}{l}\text { Menggunakan media secara efektif (mangkus) dan efesien } \\
\text { (sangkil) }\end{array}$ & 3 \\
\hline 18 & Melibatkan siswa dalam pemanfaatkan media & 3 \\
\hline 19 & Menumbuhkan partisipasi dalam pembelajaran & 3 \\
\hline 20 & Melakukan penilaian akhir sesuai dengan kompetensi dasar & 3 \\
\hline 21 & Menggunakan bahasa lisan secara efektif dan lancer & 3 \\
\hline 22 & Menggunakan bahasa tulis secara baik dan benar & 3 \\
\hline 23 & Melakukan refleksi & $\mathbf{3 8}$ \\
\hline 24 & $\begin{array}{l}\text { Melibatkan siswa dalam merangkum dalam kegiatan } \\
\text { pembelajaran }\end{array}$ & 3 \\
\hline & Skor rata-rata & 3 \\
\hline
\end{tabular}

Berdasarkan data yang diperoleh berkaitan dengan keterampilan membaca permulaan yang dijabarkan dalam bentuk: kelancaran, lafal dan intonasi yang tepat dan kejelasan dapat dilihat dengan perolehan skor rata-rata $85 \%$ sebagai berikut :

Tabel 6 : Hasil Kemampuan Membaca Permulaan Siswa Siklus II

\begin{tabular}{|l|l|l|}
\hline Kategori & Jumlah & Persentase \\
\hline Sangat lancar & 5 orang & $25 \%$ \\
\hline Lancar & 12 orang & $60 \%$ \\
\hline Kurang lancar & 3 orang & $15 \%$ \\
\hline Tidak lancar & & - \\
\hline
\end{tabular}

Dari hasil pelaksanaan siklus II, diperoleh hasil yang memuaskan tentang peningkatan keterampilan membaca permulaan dengan menggunakan metode 
Struktural Analitik Sintetik (SAS) siswa kelas I Sekolah Dasar Negeri Ciampea 02 Kabupaten Bogor.

\section{PEMBAHASAN}

1. Kemampuan guru merancang pembelajaran membaca permulaan melalui metode Struktural Analitik Sintetik (SAS) di kelas I Sekolah Dasar Negeri Ciampea 02 Kabupaten Bogor, telah dilakukan dengan baik dimana pada lembar Instrumen penilaian 1 siklus I dengan skor rata-rata 3,2. Dan pada siklus II dengan skor rata-rata 3,4.

2. Kemampuan guru melaksanakan pembelajaran membaca permulaan melalui metode Struktural Analitik Sintetik (SAS) di kelas I Sekolah Dasar Negeri Ciampea 02 Kabupaten Bogor, telah dilakukan dengan baik dimana pada lembar instrumen penilaian 2 siklus I dengan skor rata-rata 2,83. Dan pada siklus II dengan skor rata-rata 3,25. Dan sesuai dengan perencanaan pembelajaran yang telah dibuat dengan menggunakan metode Struktural Analitik Sintentik (SAS).

3. Kemampuan membaca permulaan melalui metode Struktural Analitik Sintentik (SAS) pada siklus I sebanyak 13 orang siswa yang masuk kategori lancar dan sangat lancar membaca atau 65\%. Pada siklus II meningkat menjadi 17 orang siswa yang masuk kategori lancar dan sangat lancar membaca permulaan atau $85 \%$ atau meningkat dari pelaksanaan tindakan siklus I sebesar $20 \%$.

\section{SIMPULAN}

Hasil penelitian yang diperoleh adalah keterampilan membaca permulaan siswa pada siklus I mencapai 65\%, dan siklus II mencapai $85 \%$, meningkat 20\%. Dengan menggunakan metode Struktural Analitik Sintetik (SAS) dapat meningkatkan kemampuan membaca permulaan siswa di kelas I Sekolah Dasar Negeri Ciampea 02 Kabupaten Bogor. Berdasarkan hasil penelitian dan simpulan dalam penelitian ini dapat disarankan hal-hal sebagai berikut.1) Seorang guru harus mampu mengkondisikan siswa untuk fokus pada pelajaran. 2) Pada keterampilan membaca permulaan, guru hendaknya lebih giat lagi membimbing dan melatih anak dalam membaca kalimat sederhana, membaca suku kata, membaca kata, dan membaca huruf dengan lafal yang jelas dan intonasi tepat. 3) Guru hendaknya dapat menyesuaikan antara metode pembelajaran dengan materi pembelajaran, sehingga siswa lebih tertarik dalam belajar dan ketepatan suatu metode dapat mempengaruhi kemampuan membaca 
permulaan bagi siswa kelas rendah. 4) dianjurkan kepada pendidik untuk menjadikan metode Struktural Analitik Sintentik (SAS) sebagai salah satu alternatif untuk pengembangan kemampuan membaca permulaan siswa di kelas rendah.

\section{DAFTAR PUSTAKA}

A.S Broto, 1982. Metodologi Proses Belajar Mengajar Berbahasa. Solo: Tiga Serangkai

Bob Harjanto, 2011. Merangsang dan Melejitkean Minat Baca Anak Anda, Yogyakarta: Manika.

Dalman, 2013. Keterampilan Membaca . Jakarta: Raja Grafindo Persada

Desmita, 2009. Psikologi Perkembangan Peserta Didik. Bandung: PT Remaja Rosdakarya

Elliot John, 1998. What is Action Research in School?. The Action Research Reader. Australia: Deakin University

Grundy Shirly, Kemmis Sthepen, 1998. Educational Research in Australia the state of the art (an overview), The Action Research Reader. Australia: Deakin Univesity

Hariyanto Agus, 2009., Membuat Anak Anda Cepat Pintar Membaca. Yogyakarta: Diva Press

Hopkins David, 2011. Panduan Guru Penelitian Tindakan Kelas (A Teacher's Guide Classroom Research). Yogyakarta: Pustaka Belajar

Henri Guntur, Tarigan, 2008. Membaca Sebagai Suatu Keterampilan Berbahasa, Bandung : Angkasa.

Kartono, dkk., Guru Kelas SD . Jakarta: Badan Pengembangan Sumber Daya Manusia Pendidikan Kebudayaan dan Penjaminan Mutu Pendidikan/BPSDMP-PMP

Kusumah Wijaya dan Dwitagama Dedi, 2009. Mengenal Penelitian Tindakan Kelas . Jakarta: PT. Indeks

Mulyono, Abdurrachman, 1999. Pendidikan Bagi Anak Berkesulitan Belajar, Jakarta : Rineka Cipta.

Rochiati Wiriatmadja, 2008. Metode Penelitian Tindakan Kelas. Bandung: PT. Remaja Rosdakarya 
16 | AR-RIAYAH : Jurnal Pendidikan Dasar vol. 2, no. 1, 2018

Sagala Syaiful, 2006. Konsep dan Makna Pembelajaran. Jakarta: Rineka Cipta

Sanjaya Wina, 2010. Strategi Pembelajaran Berorientasi Standar Proses Pendidikan. Jakarta: Prenada Media Group

S.C. Munandar Utami, 1992. Mengembangkan Bakat dan Kreatifitas Anak Sekolab. Jakarta:PT Gramedia

Slameto, 2003. Belajar dan Faktor-Faktor yang Mempengarubinya. Jakarta: Rineka Cipta

Solchan T. W., dkk, 2009. Pendidikan Bahasa Indonesia di SD. Jakarta: Universitas Terbuka

Stephen Waters Adam, 2006. Action Research in Education.

Sukardi, 2005. Metodologi Penelitian Pendidikan Kompetensi dan Praktiknya. Jakarta: PT Bumi Aksara

Sumantri Mulyani dan Syaodih Nana, 2007. Perkembangan Peserta Didik Jakarta: Universitas Terbuka

Suparno Paul , 2001. Teori Perkembangan Kognitif Piaget .Yogyakarta : Kanisius

Trianto, 2009. Mengembangkan Model Pembelajaran Tematik. Jakarta: Prestasi Pustakaraya

Wina Sanjaya, 2007. Strategi Pembelajaran Berorientasi Standar Proses Pendidikan. Jakarta: Kencana

Wijaya Cece, 1992. Kemampuan Dasar Guru dalam Proses Belajar Mengajar, Bandung: Remaja Rosdakarya

http://www.edu.plymunt.ac.uk/resined/actionresearch/arhome.hm 